these involve a radical change of diet, and for an appreciation of the reasons for 'desertion' and for dealing with it by sympathetic discussion of diff. culties rather than by penalties. $\mathrm{He}$ advocated measures to mitigate the hardships of the long journey on foot to the place of labour, which have still scarcely been taken on an adequate scale.

When in 1931 Tanganyika decided to abolish the Labour Department and add its duties to the responsibilities of administrative officers, Orde Browne resigned from the Colonial Service, but his interest in Colonial labour questions continued. His book, "The African Labourer", published in 1933, discussed the problems of labour welfare and protection from every angle and compared the practice of the different colonial Powers. In 1934 he became a substitute member of the International Labour Organisation's Committee of Experts on Native Labour, and took part in the drafting of the conventions on recruiting and contracts which have been adopted by that body. He supplied the original draft for the chapter on labour in Lord Hailey's "African Survey".

After being commissioned in 1937 to make an inquiry into conditions on the copper belt of Northern Rhodesia, where there had been serious riots, he was appointed labour adviser to the Secretary of State in 1938, and in turn visited and reported on the West Indies, West Africa, Ceylon, Mauritius and Malaya, and East Africa. The creation of a specialist Labour Department in every Colony, which he persistently advocated, is now official policy. He was created C.M.G. in 1942 and K.C.M.G. in 1947.

LUCY MaIr

\section{Prof. Walter Ramsden}

Prof. Walter Ramsden, emeritus professor of biochemistry in the University of Liverpool, died on March 26 at the age of seventy-eight. He went to Liverpool from Oxford in 1914, following Benjamin Moore in the chair of biochemistry. The subject was still in its infancy, attracting comparatively few graduates and scarcely any science students. Rams. den's teaching was mainly concerned with medical undergraduates, and for them he introduced for the first time a course of lectures in the subject, together with practical classes. These admirably covered general principles, but did not overburden the student with detail. The result was that when the medical student had passed the second M.B. examination he entered the hospital wards with an interest in the biochemical problems of disease an approach which at that time was comparatively new and exciting.

Ramsden was a shy, retiring man, and his formal lectures could scarcely be heard beyond the front two rows. Moreover, his tiny handwriting, whether on the blackboard or on paper, was difficult to read. Students often react to this situation by merciless ragging; but his gentleness and old-world courtesy captured them, especially as they appreciated that they were listening to a distinguished scholar and pioneer in his subject. In individual contacts, as when answering questions after the formal lecture, or in the practical class, he was at his best. His nicknames ("Rammer" at Oxford and "Rammie" at Liverpool) revealed the kindly affection with which his students regarded him.

His influence upon the Liverpool medical school and upon the University was that of a gentleman, a scholar and a man of science-quiet, unobtrusive, but far-reaching. He planted seeds, almost by stealth, and left them to grow.
Ramsden's main interests lay in the behaviour of proteins and of surface membranes, yet he always found time for young clinicians and others who were feeling their way towards the answers to varied problems, practical or academic. He entered unselfishly and wholeheartedly into their problems, and gave them the guidance and help of a master. $\mathrm{He}$ published comparatively little, though he wrote much that never came to publication, for he was almost exasperatingly modest and meticulous. $\mathrm{He}_{\theta}$ was rarely satisfied with what he wrote, and as he was always learning from his researches, he never reached that finality which he felt justified publication.

When he retired from the chair at Liverpool in 1930, and returned to Fellows' Room of Pembroke College, Oxford, his friends hoped that more of the material which he had accumulated would be made available for wider study and appreciation. He continued to follow his bent, bred silkworms and studied silkworm protein; but the papers which might have come never came.

He was a personality, and while he was at Liver. pool the University and the medical school felt him to be a rare and distinguished possession. A shy and most courteous host, he had a mellow humour and a fund of good stories. ROBERT COOPE

\section{Dr. Seymour Hadwen}

Isaac Seymour André Hadwen, who died recently, was born at Lees, Lancashire, in 1877. He obtained the doctorate in veterinary science at McGill University in 1902, and it is of interest to note that he was a member of a small band that studied the subject at McGill. The Veterinary School there owed its development to a considerable extent to Sir William Osler at the time when he was at the McGill Medical School. The School had a very short life, however, and closed soon after Hadwen graduated. Thereafter veterinary education in Canada was maintained on a less ambitious plane for a good many years, until the course at the Ontario Veterinary College was expanded and its graduates were admitted to the doctorate of the University of Toronto.

Hadwen joined the Health of Animals Branch of the Dominion Department of Agriculture in 1904 and worked for a good many years at Ottawa, and also in British Columbia, on a variety of animal health problems important in Canada; for the latter part of that period he held the post of chief pathologist in that Department. In 1920 he left the Department as he felt that the research branch was not developing in the way he considered it should, and joined the United States Bureau of Biological Survey as chief veterinarian and parasitologist, Reindeer Investigation, in Alaska. From 1923 until 1929 he held the post of research professor of animal diseases in the University of Saskatchewan, and in 1929 became director of the Department of Veterinary Science, Ontario Research Foundation, from which he retired in 1942.

Hadwen was an outstanding man with a great deal of the pioneer in his character. He could study minutiæ and did so constantly; but it was the wide range of biology that attracted him, the play of the environmental factors, and the struggle of animal life to maintain existence. Most of his personal work centred around parasitology, but many other subjects claimed his attention. 
Early in his professional career, Hadwen was associated with the late Prof. G. H. F. Nuttall in studies on the chemotherapy of piroplasmosis in dogs and cattle, in the course of which the fundamentally important discovery was made that trypan blue is specifically curative-a landmark in chemotherapy. He contributed largely to the literature of a problem still unsolved, namely, the causation of bovine chronic hæmaturia, a disease that is endemic in different countries. Ticks and the diseases with which they are associated interested him tremendously, and he had ample opportunity to study the problems concerned. His publications on 'tick paralysis' as it occurs in Canada are still important; the disease has since been studied in Southern Europe, Africa and Australia, but its real nature has still to be demonstrated. He contributed work on the systematic classification of ticks and on their bionomics. Warble flies interested him greatly, and he made important observations on Hypoderma bovis and studied other members of the group. Helminth parasites, too, he understood well and studied continuously.

In his later work at the Ontario Research Foundation the subjects were those of importance to the Ontario Province. Much of it was done with Dr. R. Gwatkin and various colleagues, on bovine contagious abortion, mastitis and other problems of intensive husbandry very different from those to which he devoted most of his life.

Hadwen contributed important reports on reindeer; on the management of the herds, fertility in reindeer, their diseases and the manner in which reindeer meat in Alaska could be marketed on a large scale. He had travelled in Labrador and Lapland, studying the problems that had aroused his interests in Alaska. His work and publications indicated measures necessary for the maintenance of health of the herds and the need to change methods that had led, even in such a land of wide open spaces, to seasonal over-crowding with consequent parasitic infestation and ill-health. Wild animals had claimed his attention, and his writings include observations on snowshoe hares and on seals. In addition, he made expeditions to Labrador, and with the East Arctic Patrol to Ellesmere Island.

Hadwen was a member of several learned societies and had been elected an honorary member of the Section of Comparative Medicine, Royal Society of Medicine.

W. A. Poor

\section{Mr. C. H. Creasey, O.B.E.}

THE death is announced of Clarence Hamilton Creasey at Llangerniew on May 22. Educated at the Royal College of Science, he became principal of Wellingborough Technical Institute, and inspector of technical schools under the Board of Education. $\mathrm{He}$ was the author of books on continuation and technical education and was a popular lecturer and broadcaster. He collaborated with Prof. A. S. Eve in writing the "Life and Work of John Tyndall", published in 1945; and with H. G. Wells in "Work, Health and Happiness of Mankind". His book, "Discoveries and Inventions of the Nineteenth" Century", published under the pen-name 'Edward Cressy' in 1914, was widely appreciated. Under the same pseudonym, he also wrote "An Outline of Industrial History" (1915), "A Hundred Years of Mechanical Engineering"' (1927), "Stories of Engineering Adventure" (1928), "Civil Engineering To-day" (1938). He took an active part in the organisation of education for gas engineers in association with the Institution of Gas Engineers.

\section{NEWS and VIEWS}

\section{Trinity College, Cambridge}

Aт the celebration, on June 3, of the four hundredth anniversary of the foundation of Trinity College, Cambridge, the guests of honour were the King and Queen, and the Duke and Duchess of Gloucester. As the royal guests drove across Great Court between crowds of cheering undergraduates, a fanfare of trumpets sounded triumphantly in welcome from above the Great Gate. After a short service in the College chapel, representatives of the town and the university waited upon their Majesties, and the morning's proceedings culminated in lunch in Hall. During the afternoon, a garden-party was held under ideal conditions, and representatives of many different types of College activity were presented to the King. The celebrations ended at five o'clock, except for a very fine firework display late in the evening, which included as a set piece a realistic portrait of the College founder, King Henry VIII.

An outstanding feature of the day was the speech at the luncheon by the King, proposing the health of the College. He spoke of the pleasure felt by the Duke of Gloucester and himself in returning to the College which they entered as undergraduates just after the First World War, and praised the outstanding contributions of members of Trinity in the State, in the humanities and in science. In particular, he referred to the introduction of the principles of inductive logic by Bacon, and their first flowering in the great achievements of Newton. In replying on behalf of the College, the Master also spoke of the extension of natural science in the hands of Maxwell, J. J. Thomson and Rutherford, and mentioned with regret the recent death of another famous Trinity man of science, Sir Frederick Gowland Hopkins. The Master discussed, too, the value of residential colleges in fostering breadth of vision, and encouraging friendship and the free exchange of ideas between those working in the sciences and in the arts. All the friends of Trinity will join in hoping that the contributions of the College to the solution of the problems of to-day and of the future may equal and even exceed the achievements of its illustrious past.

\section{Prof. J. H. Quastel, F.R.S.}

The Montreal General Hospital has established an Institute of Special Research and Cell Metabolism under the direction of Dr. I. M. Rabinowitch, and has appointed Dr. J. H. Quastel as director of the Enzyme Research Division and associate director of the Institute, while McGill University has simultaneously announced his appointment to a professorship in the Department of Biochemistry, the chairman of which is Prof. D. L. Thomson. Prof. J. H. Quastel graduated at the Royal College of Science, London, and went to 